\title{
Durability of Concrete After Fire Through Accelerated Carbonation Tests
}

\author{
Jaqueline de Assis Oliveira ${ }^{a} \mathbb{\complement}$, José Carlos Lopes Ribeiro ${ }^{\circledR}$, Leonardo Gonçalves Pedroti ${ }^{a}$, Camila \\ Spagol de Faria ${ }^{a}$, Gustavo Henrique Nalon ${ }^{\circledR}$, André Luis de Oliveira Júnior $^{a}(\mathbb{D}$
}

${ }^{a}$ Departamento de Engenharia Civil, Universidade Federal de Viçosa, Viçosa, MG, Brasil

Received: January 20, 2019; Revised: May 13, 2019; Accepted: June 02, 2019

\begin{abstract}
Degradation of mechanical properties and durability of reinforced concrete structures occur when they are subjected to fire situations, depending on the characteristics of the material, fire duration and the ways of fire extinguishing. Mechanical properties such as compressive strength, tensile strength and elasticity modulus are some examples of typically altered characteristics in concrete during high temperature exposure. Nevertheless, little is known about the advance of the carbonation front on fire-damaged concrete, which is a characteristic directly related to the durability of the structural system. For this purpose, the carbonation front was evaluated in specimens with characteristic strengths of $20 \mathrm{MPa}$ and $35 \mathrm{MPa}$, subjected to high temperatures $\left(200^{\circ} \mathrm{C}, 500^{\circ} \mathrm{C}\right.$ and $\left.700{ }^{\circ} \mathrm{C}\right)$ and different types of cooling (fast and slow). It was observed that the concrete durability is harmed by exposure to high temperatures and fast cooling. However, advance of the carbonation front was not verified in slow cooling situations.
\end{abstract}

Keywords: Concrete, Fire, Carbonation, Durability.

\section{Introduction}

The micro-structural properties of concrete exposed to high temperatures potentiate chemical-physical reactions in materials generating different physical-mechanical characteristics $^{1,2}$. When heated, the water vapor pressure within the concrete element increases, which then undergoes physical changes such as cracking and spalling ${ }^{1,3}$.

The recovery of pre-fire structural characteristics depends on the magnitude of the damage suffered by the concrete and reinforcement at the end of the cooling. This is the only way to know if the fire-damaged structure is safely functional or if immediate repair is needed ${ }^{4}$.

There are several previous studies dealing with the strength of concrete structural elements under fire conditions. However, few studies reported the residual mechanical strength and durability performance of post-fire exposed concrete. Regarding carbonation of cement-based materials, no previous study was found in the technical literature dealing with the durability characteristics of concrete structures after fire. Most references ${ }^{4,5,6}$ do not present quantitative data, deal superficially with the issue of structural repair in terms of mechanical parameters (strength, modulus of elasticity), and ignore chemical parameters that would evidence the reduction of the useful life of the structure. These papers also dealt with indirect tests for determination of chloride ion permeability, water permeability, absorption and sorptivity. According to the authors' knowledge, there are not previous works dealing with accelerated carbonation tests of fire-damaged cement-based materials subjected to slow or rapid cooling. Then, the present work was developed to systematically obtain new experimental data related to the advance of the carbonation front of concretes of different strength levels exposed to different high-temperature levels and types of cooling. Chemical analysis and a mathematical model based on the carbonation depths obtained through the accelerated carbonation tests were able to provide new information about the durability characteristics of fire-damaged concrete structures.

The consequences of microstructure modifications of the concrete can accelerate the entry of aggressive agents to the reinforcement. This may help to compromise the durability of the building after a fire. Thus, the reinforced concrete structures present physical damages such as color changes, displacements, reinforcement curvature and chemical attacks resulting from combustion ${ }^{5}$.

Cracking is another common pathology in this scenario since there are different coefficients of expansion between the materials that compose the structural system. Considerable movements occur, resulting in cracks of various depths ${ }^{1,7}$.

Santos et $a l .^{3}$ studied the influence of cooling and loading on the residual compressive strength of normal concrete after fire. The authors compared the air cooling method to the water quenching method, in order to simulate fire-fighting activities. Results of this study show that the cooling method 
is a determining factor in the compressive strength, especially when the water quenching method is used, as it causes great losses of strength and serious cracks in the surface of the concrete, including at lower temperatures.

The concrete protects the reinforcement in physical and chemical aspects. The first one is due to the physical barrier provided by the concrete cover on the reinforcement, whose efficiency depends on the quality and thickness of the concrete cover. The chemical protection results from the high $\mathrm{pH}$ in the aqueous solution of the concrete pores, allowing the formation of a thin protective film known as the passivating layer ${ }^{8}$.

The reinforcement corrosion due to the carbonation of the concrete is a significant problem for the reduction of the resistance and durability of the reinforced concrete structures. This legitimizes the importance of evaluating the evolution of these attacks also to fire-affected concrete ${ }^{6,8}$.

However, it is observed that most of the studies found for these situations aim to characterize the residual strength or to develop ways of recovering the initial strength of the structure. Nevertheless, there are few experimental evaluations regarding the durability criteria indicated by ABNT NBR 15575: $2013^{9}$ in order to estimate the useful life in these cases.

The ABNT NBR 6118: $2014{ }^{10}$ defines in a simplified way that carbonation is the action of the carbon dioxide $\left(\mathrm{CO}_{2}\right)$ of the atmosphere on steel reinforcement. The standard indicates preventive methods of control of reinforcement cover and cracking in concrete. In addition, it also recommends concretes with low porosity in order to make difficult the entry of aggressive agents in the concrete.

In the basic carbonation reaction, atmospheric carbon dioxide dissolves in the pore water and produces a weak carbonic acid $\left(\mathrm{H}_{2} \mathrm{CO}_{3}\right)$. Then, it dissociates and reacts with the calcium hydroxide and with the calcium silicate hydrates. Next, water formation and precipitation of calcium carbonate $\left(\mathrm{CaCO}_{3}\right)$ occur, resulting in a reduction in the $\mathrm{pH}$ level of the concrete. As the $\mathrm{pH}$ decreases, the front progressively progresses to the interior of the concrete, reaching the reinforcement, and causing its dispassivation ${ }^{11,12}$.

Although the reduction of alkalinity is not a harmful factor to concrete, the reduction of the $\mathrm{pH}$ becomes critical for the corrosion of the reinforcement when certain conditions are gathered together. For instance, presence of water, potential difference, access to oxygen are some factors to which reinforced concrete structures are normally exposed ${ }^{13}$.

In this sense, Possan ${ }^{14}$ applied a mathematical model, using coefficients according to the type of concrete and conditions of exposure of the structures, to describe the carbon dioxide action through the concrete, being represented by Equation (A). $x_{e c}(t)=k_{c}\left(\frac{20}{f_{c}}\right)^{k_{c c}}\left(\frac{t}{20}\right)^{0.5} \exp \left(\frac{k_{a d} a d^{\frac{3}{2}}}{40+f_{c}}+\frac{k_{C O_{2}} C O_{2}^{0.5}}{60+f_{c}}-\frac{k_{U R}(U R-0.58)^{2}}{100+f_{c}}\right) k_{c e}$

where:

$x_{e c}(t)=$ average concrete carbonation depth, in mm;

$f_{c}=$ axial compressive strength of the concrete, in MPa;

$k_{c}=$ tabulated variable factor referring to the type of cement used;

$k_{f c}=$ variable factor referring to the axial compressive strength depending on the type of cement;

$t=$ age of concrete, in years;

$a d=$ content of pozzolanic admixtures in the concrete, as a percentage of the cement mass;

$k_{a d}=$ tabulated variable factor related to the pozzolanic admixture of the concrete - fume silica, metakaolin and rice husk ash - according to the type of cement used;

$U R=$ mean relative humidity, in $\% \times 0.01$;

$k_{U R}=$ variable factor related to the relative humidity, as a function of the cement used;

$\mathrm{CO}_{2}=\mathrm{CO}_{2}$ content in the atmosphere, in \%;

$k_{\mathrm{CO} 2}=$ variable factor related to the $\mathrm{CO}_{2}$ content of the environment as a function of cement;

$k_{c e}=$ variable factor related to exposure to rain depending on the conditions of structure exposure.

This work aims to estimate the time of safe use of concrete structures exposed to high temperatures, through the investigation of fire-damaged concrete specimens of different strength levels, subjected to accelerated carbonation tests. It is expected that this study contributes with valuable experimental data for the evaluation of structural concretes in a post fire situation, in the context of durability. The results of this work show how a fire-damaged concrete can be quantitatively more vulnerable to the carbonation action, implying the durability reduction.

\section{Material and Methods}

Concrete specimens (CP's) of $10 \times 6,5 \mathrm{~cm}$, were produced using CPII E-32 cement, natural quartzite sand and gneissic gravel 1. Initially, samples of the materials were collected and submitted to grain size analysis, specific mass and unit mass according to the recommendations of the ABNT NBR NM 248:2003 ${ }^{15}$, ABNT NBR NM 52:2009 ${ }^{16}$, and ABNT NBR NM 45:2006 ${ }^{17}$.

Subsequently, the reference compositions were designed through the recommendations of ABNT NBR 12655:2015: Concrete Portland Cement - Preparation, control, reception and acceptance ${ }^{18}$, in order to obtain the characteristic strengths $\left(f_{c k}\right)$ of $20 \mathrm{MPa}$ and $35 \mathrm{MPa}$, comprising two strength classes 
often used in the construction site. The following mix proportions were used for production of $20 \mathrm{MPa}$ and 35 MPa concrete specimens, respectively: 1:2.35:3.69:0.66 and 1:1.42:2.62:0.47 (cement:sand:gravel:water). For the first 24 hours, the specimens were kept in moulds. After that, they were cured by submersion in water tanks.

For the experimental tests, a total of 142 cylindrical specimens of $100 \mathrm{~mm} \times 200 \mathrm{~mm}$ was produced. The series were designed with specimens with different compressive strength levels (20 MPa and $35 \mathrm{MPa}$ ), type of cooling (fast and slow) and fire exposure temperature $\left(200{ }^{\circ} \mathrm{C}, 500{ }^{\circ} \mathrm{C}\right.$ and $700{ }^{\circ} \mathrm{C}$ ). Each series had 3 specimens for analysis of compressive strength, 1 specimen instrumented with thermocouple for internal temperature control of the concrete and 7 specimens for the carbonation tests.

Depending on the fire exposure time, the temperature of concrete elements can reach $1000{ }^{\circ} \mathrm{C}$. In order to evaluate what happens in regions of a structural element subjected to different temperature levels, it was decided to consider the following temperature levels:

$-200{ }^{\circ} \mathrm{C}$ - temperature at which all the free water present in the pores is eliminated;

$-500^{\circ} \mathrm{C}$ - temperature at which the transformation of alpha and beta quartz occurs, modifying the crystalline material morphology; and

- $700{ }^{\circ} \mathrm{C}$ - temperature immediately before the carbonation of the concrete due to the burning effect. When the temperature is below $700{ }^{\circ} \mathrm{C}$, no carbonation due to burn effect is generated. Then, it would not modify the results of the carbonation test that would be carried out subsequently.

After 28 days, the specimens were placed in a muffle furnace and subjected to the heating process. After reaching the desired temperature with stabilization between the furnace temperature and the thermocouple measurements, part of the specimens was removed and quickly cooled by water quenching during 10 minutes. The other specimens were kept inside the furnace to cool slowly for 24 hours. Subsequently, the specimens were waxed with paraffin so that just a single face remained exposed for carbon dioxide $\left(\mathrm{CO}_{2}\right)$ entry.

After the specimens preparation, the accelerated carbonation test method started. Twenty specimens measuring $10 \mathrm{~cm}$ in diameter and $6.5 \mathrm{~cm}$ high were placed into the carbonation chamber showed in Figure 1. These dimensions are the result of cutting a standard specimen of $10 \mathrm{~cm} \times 20 \mathrm{~cm}$ in three parts along the height, ensuring a height of $6.5 \mathrm{~cm}$ that is sufficient to simulate the maximum concrete cover depth required by ABNT NBR 6118: 2014 ${ }^{10}$.

The carbonation chamber was developed in the Laboratory of Construction Materials of UFV in the research

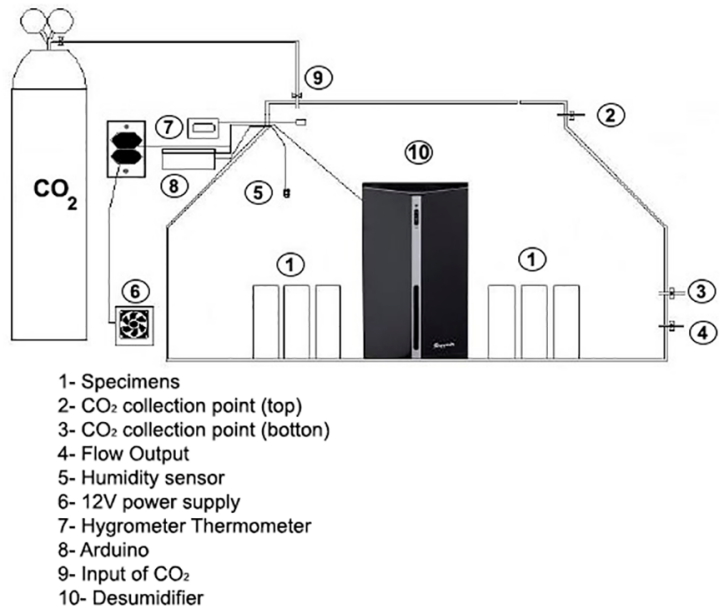

Figure 1. - Schematic of the carbonation chamber. Adapted from Martins et al. ${ }^{19}$ with permission.

conducted by Martins et $a l^{19}$. The equipment has humidity and temperature sensors, in addition to a dehumidifier controlled by an Arduino system. The system guarantees humidity levels between 65 and $80 \%$ in the atmosphere of the chamber, as recommended for conducting the accelerated carbonation tests.

The specimens were positioned inside the sealed carbonation chamber and the system passed through intercalated carbon dioxide flows until a daily concentration of $100 \%$ of $\mathrm{CO}_{2}$ was guaranteed, repeating the same process for 30 days. This same methodology of concentration was used by Kirchheim ${ }^{20}$ and Castellote ${ }^{21}$.

To measure the carbonation depth in the concrete, 2 specimens were randomly chosen from the chamber every 3 days of attack and cut horizontally. The carbonate depth measurement was performed by sprinkling $1 \%$ phenolphthalein solution in ethanol ( $\mathrm{pH}$ indicator) and calibrated with a digital pachymeter at three critical points in the sample. This solution is colorless at $\mathrm{pH}$ value lower than 8.3 and pink-carmine at $\mathrm{pH}$ values greater than 10 , and may vary from light pink to pink-carmine at $\mathrm{pH}$ values between 8 and 10. According to Hobbs ${ }^{22}$ when the concrete $\mathrm{pH}$ is below 9.5 , the reinforcement de-pulping begins. Then, when the phenolphthalein is light pink, the concrete pores $\mathrm{pH}$ is below 9. In this condition, corrosion of the reinforcement may already occur. Only when pink carmine is found the environment remains alkaline.

\section{Results and Discussion}

The Figure 2 shows the advance of carbonation front after 30 days of attack in the chamber. It is possible to observe the influence of the exposure of the CPs high 
temperature. Higher final carbonation was verified in the concrete specimens submitted to the higher temperatures and rapid cooling (RR) by water quenching, compared to the specimens that were not subject to heating. However, specimens heated and slowly cooled (RL) for 24 hours, did not present a carbonation initiation signal in none of the evaluated cases. Moreover, for the concrete compositions studied, there was an expected growth of the carbonation advance front with the increase of the water/cement ratio and, therefore, lower $f_{c k}$ as a consequence of its greater porosity.
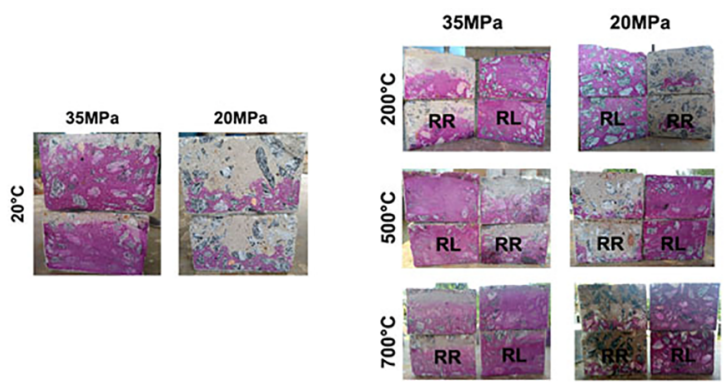

Figure 2. Carbonation advance front in the specimens.

In this sense, in case of slow cooling, it is believed that with the heating and the loss of free water present in the concrete pores, there is difficulty in the $\mathrm{CO}_{2}$ dilution and penetration through the voids of the sample. Therefore, the carbonic acid formation reaction $\left(\mathrm{H}_{2} \mathrm{CO}_{3}\right)$ is not initiated for the association after calcium hydroxide $\left(\mathrm{Ca}(\mathrm{OH})_{2}\right)$ and consequently the concrete $\mathrm{pH}$ reduction. Consequently, the precipitation of calcium carbonate $\left(\mathrm{CaCO}_{3}\right)^{23}$ does not happen.

For the cases of fast cooling, the average values of carbonation depth found for all situations of every 3 days interval of exposure in the carbonation chamber are presented in Figures 3 and 4. The predictions of durability calculated from the mathematical model of Possan ${ }^{14}$ allow comparisons between the carbonation advance fronts in fire-damaged specimens and reference concrete specimens (TR20 and TR35) that were not exposed to fire.

Observing the results it is possible to verify that the concretes exposed to the fire suffer serious durability losses compared to the reference concretes (TR), that were not exposed to fire. When comparing the fire temperatures studied, for the concrete of $f_{c k} 20 \mathrm{MPa}$, it is noticed that the elevation of the

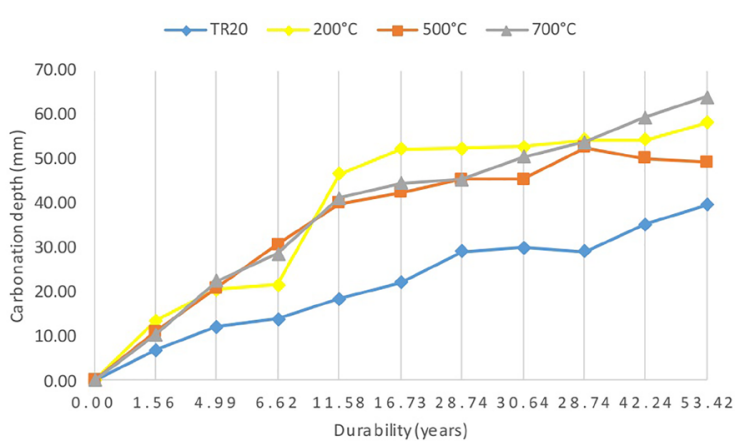

Figure 3. Carbonation depth versus durability for $20 \mathrm{MPa}$ concrete quickly cooling.

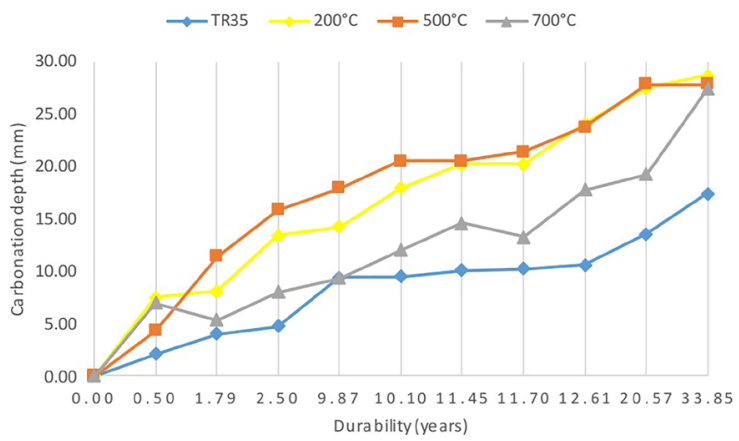

Figure 4. Carbonation depth versus durability for $35 \mathrm{MPa}$ concrete quickly cooling.

temperature was not an unfavorable factor for the advance of the carbonation front. However, in the concrete of $f_{c k} 35$ MPa considerably better results are obtained for the higher heating temperature studied compared to the temperatures of $200{ }^{\circ} \mathrm{C}$ and $500{ }^{\circ} \mathrm{C}$. In this sense, XRD analysis of the samples was performed to evaluate the $\mathrm{Ca}(\mathrm{OH})_{2}$ disposition in each situation (Figure 5).

The results show in the samples a reduction in the $\mathrm{Ca}(\mathrm{OH})_{2}$ intensity as the temperature increases, confirming the results obtained by Wang ${ }^{24}, \mathrm{Kim}^{25}$ and Peng ${ }^{26}$ in their work. Therefore, the low influence of temperature on the advance of carbonation front can be explained by the lack of calcium hydroxide for association with $\mathrm{CO}_{2}$ and formation of calcium carbonate $\left(\mathrm{CaCO}_{3}\right)$, which is responsible for the reduction of the concrete $\mathrm{pH}$, even in the cases of higher cracking, which facilitates $\mathrm{CO}_{2}$ entry. 

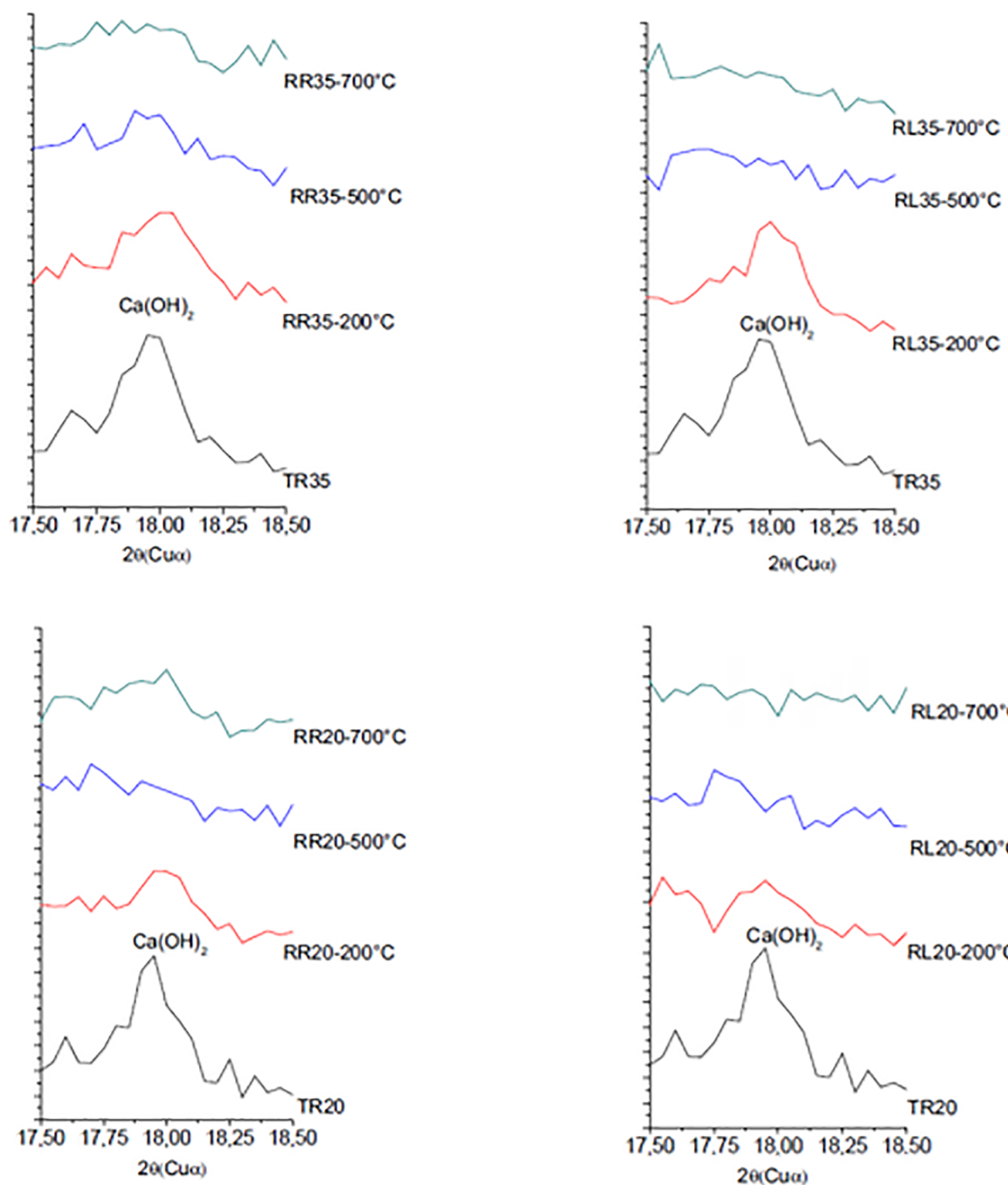

Figure 5. XRD of the evaluated concrete.

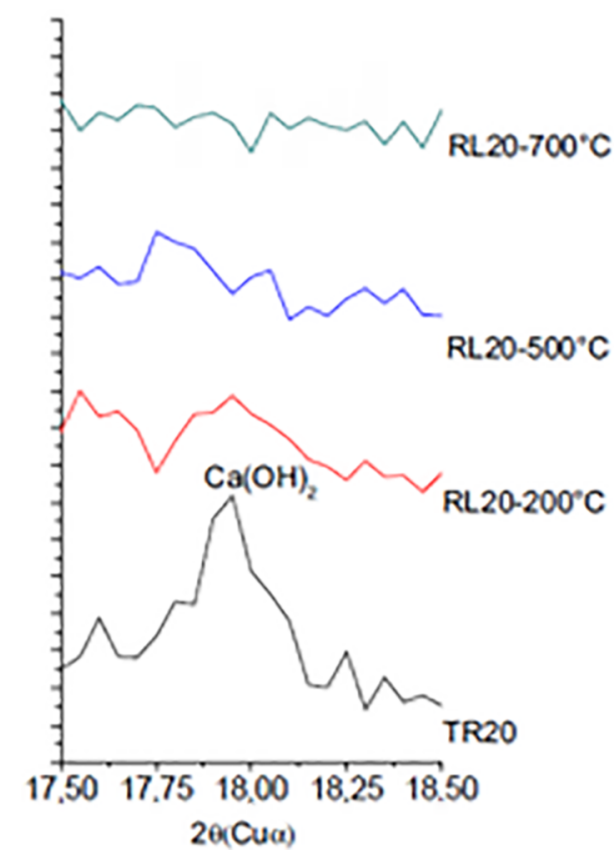




\section{Conclusions}

Based on the results, it was concluded that the effect of temperature rise on the advance of the carbonation front in the concrete can compromise the integrity of the structure and affect its durability, especially in the cases where the temperature rise is followed by fast cooling. In these situations, pore rehydration and available cracking are guaranteed ways of facilitating $\mathrm{CO}_{2}$ penetration into the concrete. Advance of the carbonation front was not verified in slow cooling situations.

Evaluations showed that the fire temperatures elevation, seems not to influence directly the advance of the concrete carbonation, since the lack availability of $\mathrm{Ca}(\mathrm{OH})_{2}$ makes impossible the formation and precipitation of $\mathrm{CaCO}_{3}$.

In addition, concrete with higher water/cement factor, lower compressive strength and higher porosity presented lower durability. Such concrete should be carefully assessed for the post-fire situation.

Subsequent studies may evaluate the influence of durability after carbonation on concretes subjected to higher temperatures and rehydration after cooling, which may be significant variables for a general evaluation of this topic.

\section{Acknowledgments}

This study was financed in part by the Coordenação de Aperfeiçoamento de Pessoal de Nível Superior - Brasil (CAPES) - Finance Code 001. The support provided by the Civil Engineering Department of the Federal University of Viçosa are also very appreciated. Last, we want to thankful Rafael F. Camarda for the help provided with the Arduino System.

\section{References}

1. Mehta PK, Monteiro PJM. Concreto: Microestrutura, Propriedades e Materiais. $3^{\mathrm{a}}$ ed. São Paulo: IBRACON; 2008. p. 150-156.

2. Fernandes B, Gil AM, Bolina FL, Tutikian BF. Microstructure of concrete subjected to elevated temperatures: physico-chemical changes and analysis techniques. Revista IBRACON de Estruturas e Materiais. 2017;10(4):838-863.

3. dos Santos CC, Rodrigues JPC, Coelho AL. Influência do processo de arrefecimento e do carregamento na resistência residual à compressão de betões normais após incêndio. In: Reabilitar 2010, Encontro Nacional Conservação e Reabilitação de Estruturas; 2010 Jun 23-25; Lisbon, Portugal.

4. Raouf-Fard MM, Nishiyama M. Residual Load Bearing Capacity of Reinforced Concrete Frames. Journal of Advanced Concrete Technology. 2016;14(10):625-633.
5. dos Santos CC, Rodrigues JPC. Reabilitação de estruturas de betão após o incêndio. In: $1^{\circ}$ Congresso de Reabilitação Urbana e SCIE; 2015 Nov 30; Lisbon, Portugal.

6. Memon AS, Shah SFA, Khushnood RA, Baloch WL. Durability of sustainable concrete subjected to elevated temperature - A Review. Construction and Building Materials. 2019;199:435-455.

7. dos Santos CC, Rodrigues JPC. Experimental testing on the residual mechanical properties of ordinary concretes after fire. In: $15^{\text {th }}$ International Conference on Experimental Mechanics (ICEM 15); 2012 Jul 22-27; Porto, Portugal.

8. Zhu X, Zi G, Cao Z, Cheng X. Combined effect of carbonation and chloride ingress in concrete. Construction and Building Materials. 2016;110:369-380.

9. Associação Brasileira de Normas Técnicas (ABNT). NBR 15575-2 - Edificações habitacionais - Desempenho - Parte 2: Sistemas Estruturais. Rio de Janeiro: ABNT; 2013.

10. Associação Brasileira de Normas Técnicas (ABNT). NBR 6118 - Projeto de estruturas de concreto - Procedimento. Rio de Janeiro: ABNT; 2014.

11. Lo TY, Liao W, Wong CK, Tang W. Evaluation of carbonation resistance of paint coated concrete for buildings. Construction and Building Materials. 2016;107:299-306.

12. Duprat F, Vu NT, Sellier A. Accelerated carbonation tests for the probabilistic prediction of the durability of concrete structures. Construction and Building Materials. 2014;66:597-605.

13. Pauletti C, Possan E, Dal Molin DCC. Carbonatação acelerada: estado da arte das pesquisas no Brasil. Ambiente Construído. 2007;7(4):7-20.

14. Possan E, Felix EF, Thomaz WA. $\mathrm{CO}_{2}$ uptake by carbonation of concrete during life cycle of building structures. Journal of Building Pathology and Rehabilitation. 2016;1:7.

15. Associação Brasileira de Normas Técnicas (ABNT). NBR NM 248 - Agregados - Determinação da composição granulométrica. Rio de Janeiro: ABNT; 2003.

16. Associação Brasileira de Normas Técnicas (ABNT). NBR NM 52 - Agregado miúdo - Determinação de massa especifica massa especifica aparente. Rio de Janeiro: ABNT; 2009.

17. Associação Brasileira de Normas Técnicas (ABNT). NBR NM 45 - Agregados - Determinação da massa unitária e do volume de vazios. Rio de Janeiro: ABNT; 2006.

18. Associação Brasileira de Normas Técnicas (ABNT). NBR 12655 - Concreto de cimento Portland - Preparo, controle, recebimento e aceitação. Rio de Janeiro: ABNT; 2015.

19. Martins ROG, Alvarenga RCS, Pedroti LG, Oliveira AF, Mendes BC, Azevedo ARG. Assessment of the durability of grout submitted to accelerated carbonation test. Construction and Building Materials. 2018;159:261-268.

20. Kirchheim AP, Rheinheimer V, Dal Molin DCC. Comparative study of white and ordinary concretes with respect of carbonation and water absorption. Construction and Building Materials. 2015;84:320-330. 
21. Castellote M, Alonso C, Andrade C, Turrillas X, Campo J. Composition and microstructural changes of cement pastes upon heating, as studied by neutron diffraction. Cement and Concrete Research. 2004;34(9):1633-1644.

22. Hobbs DW. Carbonation of concrete containing pfa. Magazine of Concrete Research. 1988;40(143):69-78.

23. Castellote M, Fernandez L, Andrade C, Alonso C. Chemical changes and phase analysis of OPC pastes carbonated at different $\mathrm{CO}_{2}$ concentrations. Materials and Structures. 2009;42(4):515-525.
24. Kim KY, Yun TS, Park KP. Evaluation of pore structures and cracking in cement paste exposed to elevated temperatures by X-ray computed tomography. Cement and Concrete Research. 2013;50:34-40.

25. Wang G, Zhang C, Zhang B, Li Q, Shui Z. Study on the hightemperature behavior and rehydration characteristics of hardened cement paste. Fire and Materials. 2015;39(8):741-750.

26. Peng GF, Huang ZS. Change in microstructure of hardened cement paste subjected to elevated temperatures. Construction and Building Materials. 2008;22(4):593-599 